\title{
Oxidation of Methylthiophenes to Thiophenecarboxylic Acids
}

\author{
Su Jin Kim and Chang Kiu Lee* \\ Deparment of Chemistry, Kangwon National Lnwersity, Chuncheon 200-701, Korea. 'E-mall ckleetloakangwon ack \\ Received Julv 30, 2009, Accepted September 21, 2009
}

Key Words: Thiophenecarboxỵlic acid. Oxidation. Assignment of chemical shifts

In the course of our continuing study on the positional effect of five-membered monoheteroaromatic compounds. ${ }^{1}$ we were in need of 3-thiophenecarboxylic acid (2a). Although 2a is commercially available. the price is about 70 times more expensive than the 2-isomer (4a). Therefore, we have explored various methods of preparation of $\mathbf{2}$ a from relatively inexpensive sources. To our surprise. there have been a small number of reports on the synthesis of 2a. One of the older methods is the conversion of 3-methylthiophene (1a) to 3-bromomethylthiophene by $\mathrm{N}$ bromosuccinimide (NBS), which is converted to 3 -thiophenecarboxaldelyde by hexamethylenetetramine. ${ }^{3}$ and subsequent oxidation of the aldehyde to $2 \mathbf{a}$ by silver oxide. ${ }^{4}$ Oxidation of 1a to 2 a was reported in a couple of patents using $N$-hydroxy phthalimide. $\mathrm{Mn}(\mathrm{OAc})_{2}$ and $\mathrm{Co}(\mathrm{OAc})_{2}$ at $150{ }^{\circ} \mathrm{C}$ for $5 \mathrm{~h}$ in $\mathrm{AcOH}^{5}$ or using $\mathrm{Co}(\mathrm{OAc})_{3}$. $\mathrm{Mn}(\mathrm{OAc})_{3}$. and $\mathrm{NaBr}$ in an autoclave at $140^{\circ} \mathrm{C}$ for $2 \mathrm{~h}^{6}{ }^{6}$ Enzymatic oxidation of the metlyl group in $\mathbf{1 a}$ to a carboxylic group was also reported with a yield of $70 \%$.

On the other hand oxidation of 1a by $\mathrm{Na}_{2} \mathrm{Cr}_{2} \mathrm{O}_{-}$using an rocking autoclave at $250^{\circ} \mathrm{C}$ for $16 \mathrm{~h}$ resulted in $2 \mathrm{a}$ in $82 \% \mathrm{yi}$ eld. ${ }^{8}$ However, the scale of the reaction was quite large ( $30 \mathrm{~g}$ of 1a $110 \mathrm{~g}$ of $\mathrm{Na}_{2} \mathrm{Cr}_{2} \mathrm{O}_{\text {; }}$ and unknown amount of water), and it was not suitable for a few gram scale. A very similar reaction was carried out at a half scale of the reactants. but a lower yield $(60 \%)$ resulted. ${ }^{?}$

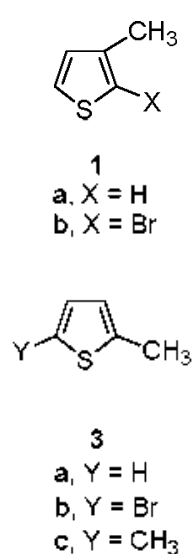

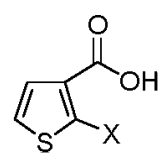

2

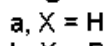

$\mathrm{b}, \mathrm{X}=\mathrm{Br}$

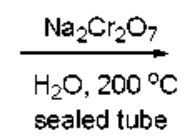

sealed tube

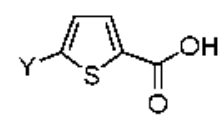

4

a, $Y=H$

b, $Y=B r$

c, $Y=\mathrm{COOH}$

3-Hydroxymethy lthiophene was oxidized photochemically in the presence of a catalytic inorganic bromo source such as $\mathrm{LiBr}$ or $\mathrm{HBr}$ to give $2 \mathrm{a}$ in $83 \%$ y ield. ${ }^{\text {l( }}$ However. the method seems to be impractical because the starting alcohol is expensive and difficult to prepare. The preparation of the Grignard reagent from 3-bromothiophene and subsequent treatment with $\mathrm{CO}_{2}$

seems to be an attractive approach to 2 a although there is a possibility of formation of $3.3^{\circ}$-bithiophene.

An alternative method for the preparation of $2 a$ is the hydrolysis of 3-cyanothiophene. ${ }^{12}$ There are a few reports for the preparation of 3-cyanothiophene from 3-bromothiophene using $\mathrm{Zn}$ powder. $\mathrm{Zn}(\mathrm{CN})_{2}$ and a catalytic anount of $\mathrm{Pd}_{2}(\mathrm{dba})_{3} \cdot{ }^{12} \mathrm{~K}_{4}[\mathrm{Fe}$ $\left.(\mathrm{CN})_{6}\right]$ and $\mathrm{Pd}(\mathrm{OAc})_{2}$ and dppf as cataly st. ${ }^{1+4}$ and $\mathrm{K}_{4}\left[\mathrm{Fe}(\mathrm{CN})_{6}\right]$. $\mathrm{Cu}\left(\mathrm{BF}_{4}\right)_{2} \cdot 6 \mathrm{H}_{2} \mathrm{O}$ and $\mathrm{N}_{2} N$-dimethylethy lenediamine in $N, N$-dimethylacetamide. ${ }^{15}$ Although the yields of cyanation are high $(80 \sim 90 \%), 3$-bromothiophene is about twice as expensive as 3-methylthiophene (1a). Therefore, we developed an efficient method of converting 1 a to $2 \mathbf{a}$. and we now report our results.

\section{Results and Discussion}

At first we attempted the Grignard reaction with 3-bromothiophene. Although the reaction with magnesium went smoothy. subsequent treatment with dry ice and acidic work-up gave a poor yield of $2 a(<20 \%)$. The major products were 3.3 '-bithiophene and thiophene. Altematively, conversion of 1a to 3-brontomethylthiophene by NBS was also troublesome when the reaction was carried out on a gram scale instead of on a 2.24 mole scale as reported. ${ }^{2}$ Therefore. we decided to explore suitable conditions for converting 1a to $2 \mathrm{a}$ in less than one gram scale using sodiun dichronate $\left(\mathrm{Na}_{2} \mathrm{Cr}_{2} \mathrm{O}_{7}\right)$.

When a mixture of $1 \mathrm{a}$ and $\mathrm{Na}_{2} \mathrm{Cr}_{2} \mathrm{O}_{-}$( $1: 1.2$ by mole) in water was heated at reflux for $24 \mathrm{~h}$. the starting la was quantitatively recovered. On the other hand. a mixture of $0.5 \mathrm{~g}$ of $1 \mathrm{a}(5.1$ mmole) and $1.8 \mathrm{~g}$ of $\mathrm{Na}_{2} \mathrm{Cr}_{2} \mathrm{O}_{-}(6.4$ mmole) in water $(8.5 \mathrm{~mL})$ was placed in a stainless steel tube (inner volume $20 \mathrm{~mL}$ ). sealed. and heated in an oil bath at $200{ }^{\circ} \mathrm{C}$ for $8 \mathrm{~h}$. After the acidic work-up, 2 a was obtained in $75 \%$ yield. Various conditions and yields are listed in Table 1.

By applying the best conditions for $0.5 \mathrm{~g}$ scale which is heating at $200^{\circ} \mathrm{C}$ for $8 \mathrm{~h}$ the oxidation of several methylthiophenes (1b. 3a-c) were carried out. The results are listed in Table 2 .

Table 1. Conditions for the Preparation of $\mathbf{2 a}$ and Yields.

\begin{tabular}{ccccccc}
\hline Entry & 1a, g & $\mathrm{Na}_{2} \mathrm{Cr}_{2} \mathrm{O}-\mathrm{g}$, & $\begin{array}{c}\mathrm{H}_{2} \mathrm{O}, \\
\mathrm{mL}\end{array}$ & $\begin{array}{c}\text { Temp, } \\
{ }^{\circ} \mathrm{C}\end{array}$ & $\begin{array}{c}\text { Time, } \\
\text { h }\end{array}$ & $\begin{array}{c}\text { Yield, } \\
\%{ }^{\circ}\end{array}$ \\
\hline 1 & 0.5 & 1.80 & 9.7 & 200 & 4 & 43 \\
2 & 0.52 & 1.90 & 9.3 & 150 & 16 & 28 \\
3 & 0.5 & 1.82 & 9.0 & 190 & 6 & 64 \\
4 & 0.5 & 1.80 & 8.5 & 200 & 8 & 75 \\
\hline
\end{tabular}

${ }^{a}$ After puritication. 
Table 2. Oxidation of Methylthiophenes.

\begin{tabular}{ccccccc}
\hline Compd & $\mathrm{Wt}(\mathrm{g})$ & $\mathrm{Na}_{2} \mathrm{Cr}_{2} \mathrm{O}-(\mathrm{g})$ & $\mathrm{H}_{2} \mathrm{O}(\mathrm{mL})$ & Product & Yield $(\%)^{6}$ & $\mathrm{Mp}$ (lit.) \\
\hline 1a & 0.50 & 1.80 & 8.5 & $2 \mathbf{a}$ & 75 & $139-140\left(137-138^{3}\right)$ \\
1b & 0.44 & 1.26 & 9.6 & 2 b & 63 & $175 \operatorname{dec}\left(176-178^{16}\right)$ \\
3a & 0.50 & 1.80 & 9.9 & $4 \mathrm{a}$ & 80 & $125-128\left(128.5^{15}\right)$ \\
3b & 0.51 & 1.01 & 10.4 & $4 \mathbf{b}$ & 93 & $135-137\left(137-138^{10}\right)$ \\
3c & 0.50 & 2.79 & 9.9 & $4 \mathbf{c}$ & 80 & $>300\left(325^{11}\right)$ \\
\hline
\end{tabular}

After purification.

Table 3. 'H NMR Data of Thiophenecarboxylic Acids in DMSO-d $d_{0}, 6$.

\begin{tabular}{|c|c|c|c|c|}
\hline & $2-\mathrm{H}$ & $3-\mathrm{H}$ & $4-\mathrm{H}$ & $5-\mathrm{H}$ \\
\hline $2 a$ & $\begin{array}{l}8.25 \mathrm{dd} \\
J=1.0,2.9 \mathrm{~Hz}\end{array}$ & & $\begin{array}{l}7.42 \mathrm{dd} \\
J=1.1,5.0 \mathrm{~Hz}\end{array}$ & $\begin{array}{l}7.60 \mathrm{dd} \\
J=3.0 .50 \mathrm{~Hz}\end{array}$ \\
\hline $2 b$ & & & $7.31 \mathrm{~d} . J=5.6 \mathrm{~Hz}$ & $7.61 \mathrm{~d}, J=5.6 \mathrm{~Hz}$ \\
\hline $4 a$ & & $\begin{array}{l}7.72 \mathrm{dd} \\
J=0.7,3.7 \mathrm{~Hz}\end{array}$ & $\begin{array}{l}7.18 \mathrm{dd} \\
J=3.7,4.9 \mathrm{~Hz}\end{array}$ & $\begin{array}{l}7.87 \mathrm{dd} \\
J=0.7,4.9 \mathrm{~Hz}\end{array}$ \\
\hline $4 b$ & & $7.54 \mathrm{~d}, J=3.9 \mathrm{~Hz}$ & $7.32 \mathrm{~d} . J=3.9 \mathrm{~Hz}$ & \\
\hline $4 c$ & & $7.7 \mathrm{~s}$ & $7.7 \mathrm{~s}$ & \\
\hline
\end{tabular}

Table 4. ${ }^{1 *} \mathrm{C}$ NMR (ppm, in DMSO- $\left.d_{6}\right)$ and IR $\left(\mathrm{cm}^{-1}\right.$, in $\left.\mathrm{CH}_{2} \mathrm{Cl} \mathrm{l}_{*}\right)$ Data of Thiophenecarbosylic Acids.

\begin{tabular}{ccccccc}
\hline & $2-\mathrm{C}$ & $3-\mathrm{C}$ & $4-\mathrm{C}$ & $5-\mathrm{C}$ & $\mathrm{C}=\mathrm{O}$ & $\mathrm{vC}=\mathrm{O}$ \\
\hline $\mathbf{2 a}$ & 133.65 & 134.67 & 128.09 & 127.64 & 163.95 & 1690 \\
2b & 119.14 & 132.58 & 129.95 & 128.23 & 163.35 & 1682 \\
$\mathbf{4 a}$ & 135.18 & 133.79 & 128.81 & 133.84 & 163.49 & 1669 \\
$\mathrm{4b}$ & 136.84 & 134.40 & 132.45 & 119.35 & 162.36 & 1662 \\
$\mathbf{4 c}$ & 140.36 & 133.77 & 133.77 & 140.36 & 162.97 & 1643 \\
\hline
\end{tabular}

It is worth noting that both of the methyl groups in 2,5-dimethylthiophene ( $3 \mathrm{c}$ ) are oxidized and that the bromo substituent in $\mathbf{1 b}$ and $3 \mathbf{b}$ does not affect the reaction.

The thiophenecarboxy lic acids 2 and + were identified by ${ }^{\mathrm{l}} \mathrm{H}$ and ${ }^{13} \mathrm{C}$ NMR spectroscopy. The results are listed in Tables 3 and 4.

Although the chemical shift values have been reported assignments of the values for the corresponding nuclei have not been made except for $\mathbf{2} \mathbf{a}$ and $\mathbf{4} \mathbf{a}^{18}$ Based on the interpretation of the coupling constants and the ${ }^{1} \mathrm{H}-{ }^{13} \mathrm{C}$ HETCOR spectra we were able to make accurate assignments for 2 and 4 . It is known that the typical coupling constants for the protons in the thiophene ring are: $J_{2.3}\left(=J_{4.5}\right)=4.8 \mathrm{~Hz} . J_{2.4}\left(=J_{3.5}\right)=1.0 \mathrm{~Hz}, J_{3.4}=3.5 \mathrm{~Hz}$, and $J_{2,5}=2.8 \mathrm{~Hz}$. ${ }^{19}$ The observed values listed in Table 3 are quite consistent with the typical values. Therefore, the proton signals are readily assigned. On the other hand, the proton-decoupled ${ }^{13} \mathrm{C}$ spectra show close values as shown in Table 4 . With the aid of the HMQC and HMBC spectra we were able to find the reported assignments ${ }^{18}$ for $4 \mathrm{a}$ are not accurate. The literature reported $5-\mathrm{C}(133.5 \mathrm{ppm})$ is further up-field than for the $3-\mathrm{C}$ (134.2 ppm). However we have found an opposite assignment for the $5-\mathrm{C}(133.84 \mathrm{ppm})$ and the $3-\mathrm{C}(133.79 \mathrm{ppm})$.

It is also interesting to observe the opposite appearance of the proton and carbon signals in $\mathbf{2 b}$. Thus, the signal of the $4-\mathrm{H}$ ( $\delta$
7.31) appears to be more up-field than that of the $5-\mathrm{H}(\mathrm{o} 7.61)$, but the signal corresponding to the $4-C(129.95 \mathrm{ppm})$ appears to be more down-field than that of the $5-\mathrm{C}(128.23 \mathrm{ppm})$. On the other hand. the $\mathrm{H}$ and $\mathrm{C}$ signals of $4 \mathrm{~b}$. which is a positional isomer of $\mathbf{2 b}$. appear in the same order

The carbonyl stretcling frequencies of the 3-isomers (2) appear at higher wavenumber $\left(1682 \sim 1690 \mathrm{~cm}^{-1}\right)$ region than those of the 2 -isomers $\left(4,1643-1669 \mathrm{~cm}^{-1}\right)$. However. the carbonyl stretching frequencies and the chenical shift of the carbonyl carbon nuclei do not show any correlation.

In conclusion. we have developed an efficient method for oxidation of methy lthiophenes to thiophenecarboxylic acids in less than gram scale using $\mathrm{Na}_{2} \mathrm{Cr}_{2} \mathrm{O}$ : and a stainless steel sealed tube.

\section{Experimental Section}

Melting points were deternined on a Fischer MEL-TEMP apparatus and are uncorrected. Nuclear magnetic resonance (NMR) spectra were recorded on a Bnuker DPX-400 FT NMR spectrometer in the Central Lab of Kangwon National University at $400 \mathrm{MHz}$ for ${ }^{1} \mathrm{H}$ and $100 \mathrm{MHz}$ for ${ }^{1 / 3} \mathrm{C}$ and were referenced to tetramethylsilane. The concentration of the solution was 0.10 $\mathrm{M}$ in DMSO- $d_{6}$. Infrared spectra were recorded on a JASCOFT/ IR-460 Plus spectrophotometer in $\mathrm{CH}_{2} \mathrm{Cl}_{2}$ solution. Methỵlthiophenes ( 1 and 3 ) are all conmercially available products and used as delivered.

Oxidation of Methỵlthiophenes. An Illustrative Procedure: A mixture of 3-methylthiophene (1a. $0.50 \mathrm{~g} .5 .1 \mathrm{mmol})$ and $\mathrm{Na}_{2} \mathrm{Cr}_{2} \mathrm{O}_{-}$( $\left.1.80 \mathrm{~g}, 6.04 \mathrm{nmol}\right)$ in distilled water $(8.5 \mathrm{~mL})$ was placed in a stainless steel tube (inuer volume $20 \mathrm{~mL}$ ) and sealed. The reactor was placed in an oil bath at $200^{\circ} \mathrm{C}$ and stirred for $8 \mathrm{~h}$. After cooling, the mixture was filtered to give a pale brown filtrate. The filtrate was acidified to $\mathrm{pH} \mathrm{l}$ by adding $\mathrm{I} \mathrm{M}-\mathrm{HCl}$ 
solution to form a precipitate. The precipitate was collected by filtration and dried to give $0.2 \mathrm{~g}$ of $\mathbf{2 a}(30 \%)$. The filtrate was extracted with ether $(2 \times 20 \mathrm{~mL})$. After drying and evaporation of the solvent $0.4 \mathrm{~g}$ of $2 \mathrm{a}(40 \%)$ was collected. The residue of the initial filtration was stirred with ether $(30 \mathrm{~mL})$ to extract additional amount of $2 \mathrm{a}(0.06 \mathrm{~g}, 10 \%)$. All the products were combined and recrystallized from water to give a pure compound of $2 \mathrm{a}(0.49 \mathrm{~g}, 75 \%)$.

Acknowledgments. We thank Dr. Gary Kwong for help in preparing the manuscript. This research was supported by Kangwon National University.

\section{References}

1. Teon, K. O; Yu, T. S : Lee, C. K. Heteroctcles 2007, 71, 153-164.

2. Campaigne, E.; Tullar, B. F. Org. Simhth. Col. Jol. II 1963, 921 923

3. Campaigne, E.; Bourgeois, R. C; McCarthy, W. C. Org. Smth. Col Fol If 1963, 918-919.

4. Campaigne, E.; LeSuer, W. M. Org. Sinth. Col. Fol. $\mathrm{IJ}^{-} 1963$, $919-921$

5. Ishii, Y.; Nakan1o, T.; Hirai, S. 2001, IP2001253838.
6. Takigawa, S. 1991, JP0 3056478

7. kiener, A. Angew. Chem. Int. Ed. Engl. 1992, 31, 774-775.

8. Friedmarlh L.; Fishel, D. L.; Shechter, H. J. Org. Chent. 1965, 30, $1453-1457$

9. Wynberg, H.; Metselaar, J. Symth. Commun. 1984, 1 t, 1-9.

10. Hirashima, S.: Hashimoto, S.: Masaki, Y.; Itoh, A. Tetrahedron 2006, 62, 7887-7891.

11. Sell, M. S.: Hanson, M. V.; Ricke, R. D. Sinth. Commun. 1994, $24,2379-2386$

12. Galvez, C.; Garcia, F; Garcia, T.; Soldevrla, J. J. Heterockchic Chem. 1986, 23, 1103-1108.

13. Erker, T.: Nemec, S. Synthesis 2004, 23-25.

14. Schareina, T.; Zapt, A.; Beller, M. Chem. Commun. 2004, 13881389 .

15. Schareina, T.; Zapf, A.; Beller, M. Tetwhedron Lett. 2005, 16 , 2585-2588.

16. Pomerantz, M.: Amarasekara, A. S.; Dias, H. V. R. J. Oig. Chem. 2002, 67,6931-6937.

17. The Merch Index, $11^{\text {th }}$ Ed.: Budavari, S., Ed.: Rahway: NJ, 1989 : $\mathrm{p} 1473$.

18. Kellogg, R. M. In Comprehensive Heterocyctic Chemisty, Katritzky, A. R.; Rees, C. W., Eds.: Volume 4, 1984: p 733.

19. Pretsch, E.; Buhlmann, P.; Affolter, C. Stncture Defermination of Organic Compounds, $3^{\text {id }}$ Ed; Springer: Berlin, 2000; 186. 